FOWLERINA EIGENMANN A PREOCCUPIED GENERIC NAME

IN the American Naturalist for 1907, p. 767, Dr. Carl H. Eigenmann proposes very magnanimously the generic name Fowlerina for a genus of stethaprionine characins. He gives Tetragonopterus compressus Günther as the type.

The name, however, is antedated by Fowlerina Pelseneer, Trans. Linn. Soc. London (2), X., February, 1906, p. 149, proposed as a new genus of mollusks.

I therefore propose the generic name EPHIPPICHARAX, and give Tetragonopterus compressus Günther also as the type. Apparently, two species are known from the Amazons, Guiana, Paraguay and eastern Brazil. The genus is remarkable for the peculiar scale-like predorsal spine, which fits into a depression in the back. It is closely allied with Stethaprion Cope. Henry W. Fowler

ACademy of Natural Sciences, PHILADELPHIA, June 12, 1913

SOME ADDITIONAL NOTES ON THE BLOWING OF sorrs

In Science, Vol. XXVIII., pp. 653-654, I published an article on the "Blowing of Soils." I wish to add these further notes on the same subject.

It has snowed here (Nett Lake, Minn.) for practically one continuous week now and more than eighteen inches of snow has fallen in that time. The snow on the ground now is three and one half feet deep. Even the ice in the lakes is so pressed down by the additional weight of snow that the water rising on it on account thereof has stopped all lake transportation and travel. But to the subject. Yesterday with a nearly west wind, bearing a little to the north, with a velocity of probably eight miles per hour, the continuous snow that fell was so filled with dirt that it was brown. It was so conspicuous that even the Indians called my attention to the dirty snow. This dirt in the snow here was the product of a dust storm somewhere. With the snow three and one half feet deep here it must have come from the country about Medicine Hat in Canada or from the northern part of the Dakotas. From conditions here it must at least have come five hundred miles.

Albert B. REAGAN

NetT Lake, MinN.,

March 20, 1913

\section{MOSQUITOES POLLINATING ORCHIDS}

IN August, 1899, seven mosquitoes bearing pollinia of the tall green orchid, Habenaria hyperborea, were taken at a camp on the Medicine Bow Range in northern Colorado, at an altitude of 10,200 feet. Four individuals carried two pollinia each; three carried one each. The viscid disks were attached to the lower front of the head and in some cases partially covered the eyes.

The captures were made on a rainy day within a tent located at some little distance from the stream on the banks of which the orchid grew. Examination of a considerable number of spikes showed that pollinia had been removed from many of the flowers, but actual removal by mosquitoes was not observed. Mosquitoes were extremely abundant, only a relatively small number was examined and few carried pollinia, but the impression remains that this undetermined species of mosquito may be regarded as of some importance as an agent in the pollination of this Habenaria.

This observation was recorded in The Plant World, 3: 6, January, 1900.

\section{UNIVERSITY OF ILLINOIS}

\section{S. Crandall}

\section{PLUS AND MINUS AGAIN}

Dr. Halsted's statement ${ }^{1}$ on the use of the symbol + in Widman's arithmetic of 1489 is apparently in conflict with my own. ${ }^{2}$ As neither Widman's book nor the descriptions of it in the Bibliotheca mathematica ${ }^{3}$ are readily accessible to most American readers, it may be well to give a fuller account. The

1 ScIence, May 30, 1913, p. 837.

2 SCIEnCe, April 18, 1913, p. 610.

3. F., Bd. 9, 1908-09, pp. 155-157, 248; Bd. 10, 1909-10, pp. 182, 183. 